УДК 61:681.03:618.177-089.888.11

\title{
ПРОГНОЗУВАННЯ СТАНІВ І ЕФЕКТУ ПРИ ДОПОМІЖНИХ РЕПРОДУКТИВНИХ ТЕХНОЛОГІЯХ НА ОСНОВІ БАГАТОРІВНЕВИХ ОНтолОГІй
}

\author{
С. В. Денисенко \\ Національна медична академія післядипломної освіти імені П. Л. Шупика \\ Проаналізовано можливість прогнозування на основі онтологічного представлення знань щодо допоміжних реп- \\ родуктивних технологій. Показано можливість використання орієнтованих графів для задач прогнозування.
}

Ключові слова: допоміжні репродуктивні технологі, багаторівневі онтологі, прогнозування станів, діагностичні детермінанти, фактори ризику, орієнтований граф.

\section{ПРОГНОЗИРОВАНИЕ СОСТОЯНИЙ И ЭФФЕКТА ПРИ ВСПОМОГАТЕЛЬНЫХ РЕПРОДУКТИВНЫХ ТЕХНОЛОГИЯХ НА ОСНОВЕ МНОГОУРОВНЕВЫХ ОНТОЛОГИЙ}

\author{
С. В. Денисенко \\ Национальная медицинская академия последипломного образования \\ имени П. Л. Шупика
}

\begin{abstract}
Рассматривается решение задачи прогнозирования на основе онтологического представления знаний о вспомогательных репродуктивных технологиях. Выделяется ряд уровней оказания медицинской помощи пациентам с проблемами бесплодия. При этом на каждом уровне множеством сохранившихся в памяти элементов информации с заданным на нем бинарном отношению, индуцированным ассоциативными связями между различными элементами, взаимно однозначно ставится в соответствие ориентированный связный граф $G$.

Прогнозирование обеспечивается использованием решающего правила, ориентированного на вычисление показателя возникновения прогнозируемого состояния. Он рассчитывается путем сопоставления вероятностей перехода из исходных состояний, имеющихся у пациента, в предполагаемый с вероятностью перехода из других состояний в тот же анализируемый элемент графа. Показана возможность практической реализации предлагаемого подхода. Показано, что точность прогнозирования для первого периода накопления данных вполне убедительна и составляет $(88,2 \pm 4) \%$.
\end{abstract}

Ключевые слова: вспомогательные репродуктивные технологии, многоуровневые онтологии, прогнозирования состояний, диагностические детерминанты, факторы риска, ориентированный граф.

\section{PROGNOSTICATION OF THE STATES AND EFFECT IN ASSISTED REPRODUCTIVE TECHNOLOGIES ON THE BASIS OF MULTI-LEVEL ONTOLOGIE'S}

S. V. Denysenko

National Medical Academy of Post-Graduate Education by P. L. Shupyk

\begin{abstract}
The problem of prediction on the basis ontological knowledge representation of assisted reproductive technologies is considered. A number of levels medical care for patients with infertility problems is identified. At each level the set of surviving in the memory elements of information given on it with a binary relation induced by associative links between the various elements, bijectively is assigned oriented connected graph $\mathrm{G}$.

Forecasting is ensured by using a decision rule oriented on the computation of projected state indicator. It is calculated by comparing the transition probabilities of the initial states available to patient, in prospective with probability of transition from other states in the same analyzed element graph. Demonstrated possibility practical implementation of the suggested approach. The forecasting accuracy for the first period accumulation of data completely persuasive and is (88,2 \pm 4$) \%$ is shown.
\end{abstract}

(C) С. В. Денисенко 
Key words: assisted reproductive technology, multi-level ontologies, prediction states, diagnostic determinants, risk factors, directed graph.

Вступ. Ефективність допоміжних репродуктивних технологій (ДРТ) у вирішенні проблеми фертильності на концептуальному рівні не викликає сумнівів. Водночас різнорідність чинників, які впливають на ефективність методів подолання безплідності та стану репродуктивної системи подружжя, робить завдання аналізу медичної та економічної ефективності методів подолання безплідності вельми складним.

Саме тому кількісне визначення факторів, які підвищують ризик безпліддя і які впливають на ефективність ДРТ та їх взаємозв'язку, вельми актуальне, а систематизація виявлених факторів забезпечить створення моделі прогнозування результатів ДРТ.

Мета дослідження: надати уявлення про ефективність прогнозування результатів допоміжних репродуктивних технологій на основі онтологічної бази знань.

Матеріали і методи дослідження. У роботі використані класичні ідеї застосування предметних онтологій в медичній практиці $[1,2]$.

У попередньому нашому повідомленні [3] було детально представлено алгоритм прогнозування. На даному етапі роботи розглянуто двоплошинну логіку прогнозування. Як і раніше, на кожному рівні безлічі збережених у пам'яті елементів інформації з заданим на ньому бінарним відношенням, індукованим асоціативними зв' язками між різними елементами, взаємно однозначно ставиться у відповідність орієнтований зв' язний граф $G$.

Кожному елементу інформації $a(a \in \Omega)$ відповідає вершина і графа $G$, а будь-які дві вершини $i, j$ $(i, j \in G)$ з'єднані дугою, якщо відповідні елементи $a_{i}, a_{j} a \in \Omega$ перебувають у відношенні, визначеному на $\Omega$. Безліч $\Omega$, а отже, граф $G$ - кінцевий. Граф без контурів, вершини графа інтерпретуються як стан організму (рис. 1).

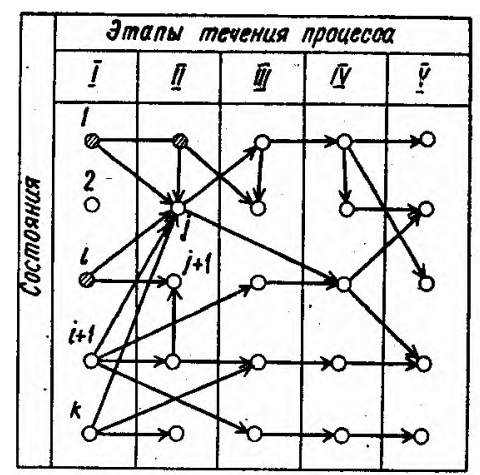

Puc. 1. Метод подання перебігу захворювань у вигляді графа.
Таким чином, якщо у пацієнта є кілька станів, інтерпретованих як деяка множина вершин графа $G$, то процес розвитку патологічного процесу розглядається як передача інформації попарно інцидентним його вершинам і вибір з безлічі задіяних у процесі вершин послідовності, шо задовольняє певні умови. Кожній вершині $x$ графа $G$ поставлено у відповідність три дійсних невід`ємних числа: ії вага, поріг і міра довіри до інформації $-S_{x} n_{x} i \Theta_{x}$.

Питання являють собою $k$-мірні вектори $\vec{v}\left(v_{1}, v_{2}, \ldots, v_{k}\right)$. де $v_{i}=\left\{\frac{1}{0}, a k-\right.$ число вершин графа. Відповідь, що видається системою, також $k$-мірний вектор $\vec{\omega}=\left(\omega_{1}, . \omega_{k}\right)$, де $\omega_{i}=\left\{\frac{1}{0}\right.$.

Кожній дузі $i j$ графа $G$ співвіднесено дійсне невід'ємне число $p_{i j}\left(0 \leq p_{i j} \leq 1\right)$, яке можна інтерпретувати як ймовірність переходу з вершини $i$ до вершиниј.

Принципово прогностична система містить два оператори: $F$ i $Q$. Оператор $F$ служить для попереднього відбору в $G$ інформації, що відноситься до заданого запитання $\vec{v}, \mathrm{i}$ ставить у відповідність вектору $\vec{v}$ граф $T \vec{v}(T \vec{v} \leq G)$. За допомогою оператора $Q$ в графі $T \vec{v}$ будується відповідь $\vec{\omega}$.

Для кожної вершини $x$ визначається числова функція $\Psi_{x}^{v}$, що залежить від ваги вершин, які є початком дуг, кінець яких $x$, і від питання $\vec{v}$.

Оператор $Q$ реалізовано арифметичною функцією. Iї вибір визначається особливостями завдання і ступенем складності патологічного процесу. У простому випадку, якщо під вершиною графа розуміти стан хворого, то прогнозування перебігу процесу можна здійснювати за допомогою

$$
\pi=p_{i j} S_{i} \Theta_{i j}-\Sigma p_{k j} S_{k} \Theta_{k j}
$$

де $p_{i j}$ - ймовірність переходу 3 наявного стану пацієнта в прогнозований; $p_{k j}$ - ймовірність переходу 3 невиявлених станів пацієнта в прогнозований; $\Theta_{t j}-$ міра довіри до значень $i$-стану в плані вирішення конкретного завдання діагностики або прогнозування, j-стану складніших випадків, коли під вершиною розуміють градації симптомів, показників і т. д., арифметична функція може бути такою:

$$
\pi_{j}=\Sigma p_{i j} S_{i} \Theta_{i}-\Sigma p_{k j} S_{k} \Theta_{k}
$$

Кількість рівнів $i$ тимчасові інтервали вибрані рівними одному дню. Відповідно до останніх змінюються ймовірності ускладнень, станів тощо. 
Проміжкки між рівнями вибираються так, щоб усередині проміжку ймовірності ускладнень були приблизно рівні, і за час, який відповідає кожному проміжку, спостерігався ефект лікарських препаратів.

Результати та їх обговорення. Контент медичної бази знань $з$ проблем використання допоміжних репродуктивних технологій, очевидно, повинен узагальнювати не тільки власні спостереження, а й відображати накопичений досвід відносно проблеми. У цьому відношенні проблемно-орієнтовані онтології повинні не тільки забезпечити накопичення даних, a й перевірку їх на сумісність 3 раніше зібраними матеріалами. Тому моніторинг контенту є обов'язковою процедурою, а коефіціснт $\theta$ повинен враховуватися у всіх процедурах як міра довіри в показнику. Але ж його обгрунтування (як і вибір чинників для розв'язання задач прогнозування) являє собою складну проблему. Покажемо на прикладі логіку обгрунтування показників для системи прогнозування. Використаємо для цього огляди літератури, зокрема [4]. Діасностичні детермінанти та фактори ризику при ДРТ. Традиційно серед факторів ризику розглядаються наступні фактори: вік жінки, причини безпліддя, кількість попередніх циклів ЕКЗ, кількість перенесених ембріонів [4]. Ці чинники, разом з іншими клінічними показниками, проаналізовані J. Castilla і співавт., які вивчили 25462 циклів у 75 клініках у пошуках методів оцінки результативності допоміжної репродукції за даними реєстру ЕКЗ/ІКСІ. Близькі результати отримані Lintsen і співавт. [6], які оцінювали ймовірність настання вагітності залежно від віку жінки, тривалості безпліддя, результату попередніх вагітностей. У дослідженні взяли участь 4928 сімейних пар з безпліддям. За сімейними парами протягом 12 міс. проводилося спостереження 3 використанням баз даних 11 центрів і 20 клінік ЕКЗ. У середньому за 12 міс. парам було проведено по 1,8 цикла EK3 і IKСІ. Ймовірність настання вагітності протягом року склала $44,8 \%$ (при $95 \%$ ДІ 42,1-47,5\%). Автори дійшли до висновку, що найважливішими прогностичними ознаками, які визначають ймовірність настання вагітності після ЕКЗ і ІКСІ, $\epsilon$ вік жінки (позитивні результати найчастіше відзначалися у 30-річних жінок, трохи рідше - у більш молодих жінок і значно рідше - у жінок старше 35 років). Значимість таких показників, як тривалість безпліддя і попередні вагітності, обмежена. При порівнянні результатів з дослідженням, проведеним A. Templeton i A. Stolwijk в 1996 p. [7], вони отримали досить суперечливі дані внаслідок невідповідності діагностичних груп.
3 іншого боку, за даними Т. А. Назаренко та співавт. [7], частка пацієнток старшого репродуктивного віку, які звернулися з приводу безпліддя в 1995 р., становила $20 \%$, до 2003 р. зазначалося різке збільшення числа цих пацієнток до $37 \%$. Фізіологічний процес поступового згасання функції яєчників - одна з основних перешкод на шляху ефективності програм EK3.

Отже, ефективність ДРТ залежить від віку пацієнтки і стану оваріального резерву і менше залежить від обраних схем індукції овуляції. Умовно перспективним можна вважати вік до 41 року, що обумовлює доцільність використання ооцитів донора у жінок старше цього віку [7].

Вік чоловіка позначається на частоті зачать: після 35 років цей показник знижується, оскільки якість сперми до даного віку погіршується. За даними літератури, середній вік одружених батьків постійно збільшується. Однак, при віці партнера 30-34 роки середній ризик природного переривання вагітності складає $16,7 \%$, якщо чоловікові 35-39 років, цей показник зростає до 19,5\%, якщо ж 40 років або більше - до $33 \%$. Правда, зазначені дані стосуються ведення вагітності у пар, які пройшли курс внутрішньоматкової інсемінації (BMI) за результатами ВМІ спермою партнера [8].

Вік пацієнток $€$ серйозним прогностичним фактором, який визначає успіх лікування в програмі ЕКЗ і ПЕ, при цьому повної ясності в питанні про вплив віку чоловіка на успішність цих програм не досягнуто.

До теперішнього часу думки про вплив надмірної маси тіла та ожиріння на ефективність програм ЕКЗ неоднозначні. Розглядаючи прогностичне значення індексу маси тіла, слід зазначити, що у 40 \% жінок, які звертаються за медичною допомогою в центри 3 лікування безпліддя, $є$ надлишкова маса тіла, понад $15 \%$ страждають ожирінням. Виходячи з їхніх апріорних міркувань, переважно проведення програми ЕК3 після нормалізації маси тіла. Проте, дуже часто пацієнткам не вдається знизити масу тіла до бажаних показників. Тому доводиться проводити стимуляцію суперовуляції на тлі надлишкової маси тіла та ожиріння. Дослідження, що вивчають вплив ожиріння на ефективність лікування з використанням ЕК3, нечисленні, а отримані результати часто суперечливі. За даними А. Maheshwari і співавт. [9], які об'єднали результати 37 досліджень, пацієнтки 3 індексом маси тіла (IMT) $>25$ кг $/ \mathrm{M}^{2}$ мають менше шансів настання вагітності після ЕКЗ, порівняно 3 жінками з ІМТ $<25$ кг $/ \mathrm{M}^{2}$ (ОШ 0,62-0, 81; 95 \% ДІ $0,62-0,81)$. 
В інших дослідженнях показано, що жінки 3 надмірною масою тіла та ожирінням мають такі ж шанси на успішне лікування за допомогою ЕКЗ, як і жінки 3 нормальною масою тіла. Відмінностей за частотою настання вагітності, прогресуючої вагітності і частотою пологів живим плодом між окремими групами виявлено не було [10].

Не встановлено прямого впливу на ефективність лікування безпліддя алергічних реакцій, абортів і пологів в анамнезі, числа спроб лікування шляхом ЕКЗ, форми безпліддя, хоча допускається опосередкований вплив [11]. Незважаючи на відносно досить високі результати застосування ICSI при лікуванні безпліддя, обумовленого чоловічим фактором, необхідно підкреслити особливе значення генетичного скринінгу інфертильних пацієнтів, які потребують застосування цього методу. Цілою низкою досліджень доведено, що чоловіки 3 тяжкими формами олігоастенотератозооспермії навіть при нормальному каріотипі складають групу високого ризику як носії різних генетичних дефектів в статевих клітинах (хромосомного дисбалансу, мутацій Ү-хромосоми або гоносомної анеуплоїдіï), які можуть передаватися потомству чоловічої статі, обумовлюючи в статевозрілому віці аналогічну форму субфертильності або навіть інфертильності у синів.

Показана пряма кореляція між концентрацією сперматозоїдів в еякуляті і частотою хромосомних аномалій, яка складає при нормозооспермії $2,2 \%$ i збільшуеться до 5, 1 \% при олігозооспермії, 14,6 \%при азооспермії і 20,3 \% - при необструктивній азооспермії. При цьому особлива увага приділяється молекулярним методам діагностики мікроделецій в AZF-ділянці довгого плеча Y-хромосоми, шо зустрічаються, за даними різних авторів, у 5-18 \% чоловіків з ідіопатичною азооспермією або тяжкою олігозооспермією [12]. У фертильних пацієнтів частота мікроделецій Ү-хромосоми не перевищує $2 \%$.

Зазначимо, що в задачі прогнозування потрібно враховувати той факт, що і сама процедура виконання ICSI, яка включає аспірацію ооплазми, несе потенційний генетичний ризик у зв'язку з можливим порушенням мейотичного веретена, що може обумовлювати більш високу частоту поліплоїдії, анеуплоїдії або мозаїцизму в ембріонах після ICSI, ніж після класичного запліднення in vitro. Зважаючи на той факт, що частота народжкення дітей 3 хромосомними аномаліями у інфертильних чоловіків у 10 разів вища, порівняно з загальною популяцією, де цей показник становить $0,6 \%$, у разі настання вагітності після виконання ICSI повинна бути рекомендована пренатальна і преімплантаційна генетична діагностика (ПГД). Остання являє собою інвазивний метод оцінки ембріонів, який використовують для виявлення анеуплоїдії хромосом, наявності структурних перебудов хромосом, визначення статі, діагностики моногенної патології. Показниками для проведення преімплантаційної діагностики $\epsilon$ такі чинники: вік матері понад 35 років, наявність збалансованої перебудови у одного з батьків, невдачі проведення декількох циклів допоміжної репродуктивної технології (ДРТ) в анамнезі, звичне невиношування, наявність $\mathrm{X}$-зчепленої патології в анамнезі, соціальні чинники. Зауважимо, що для проведення преімплантаційної генетичної діагностики застосовують молекулярноцитогенетичні (FISH, CGH) і молекулярні (ПЛР) методи.

Добре відомо, що у пацієнток з безпліддям, які готуються до програми екстракорпорального запліднення, відзначають зміни показників імунного статусу. Більш виражені ці відхилення в групі пацієнток 3 аутоімунними захворюваннями. Зміни імунного статусу у пацієнток з аутоімунними захворюваннями представлені зниженням відносної чисельності Влімфоцитів у $57,9 \%$, підвищенням числа Т-хелперів у 70,8 \% і Т-цитотоксичних лімфоцитів у $54,2 \%$, зниженням абсолютного числа NK-лімфоцитів у $62,5 \%$, високим вмістом ЦПК у 68 \% пацієнток, порівняно 3 референтними значеннями здорових жінок $(\mathrm{p}<0,05)$. У пацієнток з трубно-перитонеальним безпліддям, які не мають аутоімунних захворювань, зміни імунного статусу представлені підвищеним вмістом Т-хелперів у 75,8 \% і ЦІК у 57,1 \% пацієнток.

Наявність HLA-антигенів B18, Cw3 і Cw4, наявність в анамнезі хронічного чи гострого аднекситу і кількість тромбоцитів венозної крові у пацієнток, які мають аутоімунні захворювання, $\epsilon$ прогностично значущими факторами при прогнозуванні результативності застосування екстракорпорального запліднення. Разом з тим, між різними методами класифікації результативності існують значні невідповідності.

Прогнозувания результатів ДРТ. Використання перерахованих діагностичних і прогностичних детермінант дало можливість отримати результати прогнозування результатів ДРТ, представлені в таблиці 1.

Як бачимо з наведених даних, прогнозування як загального результату ДРТ, так і провідних ускладнень дозволяс отримати хороші результати. Природно, що числа спостережень ще недостатньо, щоб робити остаточні висновки, однак характер тенденцій очевидний. 
Таб̆лиця 1. Результати прогнозування результатів ДРТ

\begin{tabular}{|c|c|c|c|c|c|}
\hline \multirow[t]{2}{*}{ Процедура прогнозування } & \multirow{2}{*}{$\begin{array}{c}\text { Число } \\
\text { випадків }\end{array}$} & \multirow{2}{*}{$\begin{array}{c}3 \text { несприятливим } \\
\text { результатом } \\
\text { (ускладненнями) абс. }\end{array}$} & \multicolumn{2}{|c|}{$\begin{array}{c}\text { Успішне } \\
\text { прогнозування }\end{array}$} & \multirow[t]{2}{*}{$\pm \mathrm{m}, \%$} \\
\hline & & & абс. & $\%$ & \\
\hline Прогнозування успішності ДРТ & 65 & 17 & 15 & 88,2 & 4 \\
\hline Прогнозування провідних ускладнень & 65 & 12 & 10 & 83,3 & 4,6 \\
\hline
\end{tabular}

Висновки. 1. Запропоновано рішення задачі прогнозування на основі онтологічного представлення знань щодо допоміжних репродуктивних технологій. Показано, що точність прогнозування складає $(88,2 \pm 4) \%$.

\section{Лiтература}

1. Клещёв А. С. Модель онтологии предметной области : Медицинская диагностика. - Часть 1. - Неформальное описание и определение базовых терминов / А. С. Клещёв, Ф. М. Москаленко, М. Ю. Черняховская // НТИ. Сер. 2. 2005. - № 12. - C. 1-7.

2. Клещёв А. С. Модель онтологии предметной области : Медицинская диагностика. - Часть 2. - Формальное описание причинно-следственных связей, причин значений признагов и причин заболеваний/ А. С. Клещёв, Ф. М. Москаленко, М. Ю. Черняховская // НТИ. Сер. 2. - 2006. - № 2. -C. 19-30.

3. Денисенко С. В. Принципи та логіка побудови бази знань по допоміжних репродуктивних технологіях / С. В. Денисенко // Медична інформатика та інженерія. - 2013. - № 4. - C. 20-23.

4. Амирова А. А. Факторы, влияющие на исходы ЭКО : обзор литературы / А. А. Амирова, Т. А. Назаренко, Н. Г. Мишиева // Проблемы репродукции. -2010 . - № 1. C. 68-74.

5. Castilla J. А. Определение вероятности низкой и оптимальной результативности в программах ЭКО/J. A. Castilla [et al.]//Human Reproduction. - 2008. - Vol. 23, № 1 - P. 8590.

6. Linsten A. М. Прогнозирование вероятности развития беременности после ЭКО и ИКСИ : национальное проспективное исследование / А. М. E. Linsten [et al.] // Human Reproduction. - 2007. - Vol. 22, № 9. - P. 2455-2462.
2. У вирішальному правилі прогнозування повинен брати участь показник довіри до отриманої інформації.

7. Значение овариального резерва в лечении бесплодия у женщин старшего репродуктивного возраста / Т. А. Назаренко, Н. Г. Мишиева, Н. Д. Фанченко [и др.] // Проблемы репродукции. -2005 . -№ 2. - С. 56-59.

8. Menezo Y. Scientists warn that biological clock affects male fertility / Y. Menezo // Guardian. - 2008. - №2.

9. Maheshwari A. Effect of overweight and odesity on assisted reproductive technology - a systematic review / A. Maheshwari, L. Stofberg, S. Bhattacharya // Human Reproduction Update. - 2007. - Vol. 13, № 5. - P. 433-444.

10. The direct health services costs of providing assisted reproduction services in overweight or obese women: a retrospective cross-sectional analysis / A. Maheshwari, G. Scotland, J. Bell [et al.] // Human Reproduction - 2009. Vol. 24, № 3. -P. 633-639.

11. Магер Г. М. Влияние различных факторов на эффективность лечения бесплодия методом ЭКО и прогнозирование результатов применения : автореф. дисс. на соискание научной степени канд. мед. наук / Г. М. Магер. - М., $1993 .-175 \mathrm{c}$.

12. Ultrasonic monitoring during replacement of frozen/thawed embryos in natural and hormone replacement cycles / T. AlShawaf, D. Yang, Y. Al-Magid [et al.] // Human Reproduction. - 1993. -№ 8. - P. 2068-2074. 